\title{
A INFLUÊNCIA DA TEORIA ÉTICA DE ADAM SMITH NO JOVEM ENGELS
}

\author{
THE INFLUENCE OF ADAM SMITH'S ETHICALTHEORY ON THE YOUNG \\ ENGELS
}

\author{
Franco Maximiliano Rodríguez Migliarini ${ }^{1}$ \\ (francorodriguez1@hotmail.es)
}

\begin{abstract}
RESUMO
No presente artigo analiso a influência da teoria ética smithiana nos dois primeiros trabalhos do jovem Engels, isto é, Esboço de uma crítica da Economia Política e A situação da classe trabalhadora na Inglaterra. Assim, na primeira parte, abordo as principais características da teoria ética smithiana apresentadas no seu livro Teoria dos sentimentos morais, principalmente, a ideia de corrupção dos sentimentos morais, as quais, segundo estimo, influenciaram o pensamento do jovem Engels. Na segunda parte, analiso os dois textos de Engels acima referidos e aponto para os pontos em contato com os postulados smithianos previamente elencados.
\end{abstract}

Palavras-chave: Adam Smith. Marx. Engels. Economia. Teoria econômico-política.

\begin{abstract}
The paper analyzes the influence of Smith's ethical theory on Engels' first two works, namely: Outlines of a Critique of Political Economy and The Condition of the Working Class in England. Thus, in the first part, it discusses the main features of Smith's ethical theory presented on his book The Theory of Moral Sentiments, especially the idea of corruption of moral sentiments that - so our thesis - influenced young Engels' thought. In the second part, it analyzes both Engels' texts mentioned above and it shows the points of contact with the previously pointed theses by Smith.
\end{abstract}

Key-words: Adam Smith. Friedrich Engels. Ethics. Political Economy. Corruption of Moral Sentiments.

[Q]uando o Lutero da economia, Adam Smith, fez a crítica da economia anterior, muito já mudara. O século humanizara-se, a razão soubera impor-se, a moral começava a fazer valer seu direito eterno. (ENGELS, 1979, p. 5)

\footnotetext{
${ }^{1}$ Doutor em Filosofia pela Universidade Federal de Santa Catarina (UFSC).

CV Lattes: http://lattes.cnpq.br/7250054313034803.
} 


\section{INTRODUÇÃ̃O}

Resulta claro que a compreensão da obra econômica de Smith é uma condição sine qua non para compreender as grandes teses econômicas marxianas. Nesse sentido, muito tem sido escrito sobre a influência da teoria econômico-política de Adam Smith na obra de Marx, principalmente, no que se refere à formulação do seu conceito de valor e sua a crítica do maisvalor. Porém, um elemento que não é, via de regra, levado em consideração, é que Adam Smith não marcou o rumo da produção filosófica de Marx, senão que ele, certamente, teve um grande impacto nos trabalhos do outro fundador da teoria marxiana, Friedrich Engels, filósofo alemão, quem, na sua juventude, publica trabalhos os quais abordam questões de caráter econômico/social, mas também normativas. Com base nesta percepção, neste trabalho, me proponho apontar para os pontos de contato que existem entre a teoria ética smithiana e as considerações de caráter ético/normativo do jovem Engels. Assim, dividirei o presente artigo em duas grandes partes. No primeiro momento, apresento alguns dos elementos pilares da teoria smithiana. Nesse ponto, cabe fazer a ressalva que não abordarei de forma completa a teoria dos sentimentos morais. Muito pelo contrário, somente aprofundarei os elementos que, logo, servirão para estabelecer vínculos entre tal teoria ética e os postulados éticos nos dois primeiros trabalhos de Engels. Por tal motivo, muito dos principais elementos da teoria ética smithiana, tais como seu famoso procedimentalismo ético do observador imparcial e aspectos fundamentais do seu conceito de simpatia, não serão abordados. Posteriormente, apontarei para aquilo que considero ser um dos principais legados da teoria smithiana na obra do jovem Engels.

\section{TEORIA ÉTICA SMITHIANA E CORRUPÇÃO DOS SENTIMENTOS MORAIS}

A seguir, começarei por apresentar a concepção de natureza humana do autor. Somente depois de realizada tal análise, apresentarei alguns dos elementos pilares da sua teoria ética para, finalmente, chegar à sua tese da corrupção dos sentimentos morais do ser humano.

\subsection{A natureza e natureza humana em Smith}


Smith possui uma concepção sobre a Natureza claramente pré-darwiniana. Grosso modo, isso significa que nosso autor concebe a Natureza como sendo uma entidade que age no mundo de forma volitiva. Trata-se de uma força com certas faculdades e é responsável pelo fato de certas coisas no mundo serem do jeito que são ${ }^{2}$. Em outras palavras, a ideia que Smith possui de Natureza não difere em grande medida da ideia Natureza dos pensadores gregos pré-clássicos e clássicos. Para eles a $\Phi v ́ \sigma ı \varsigma$, isto é, o que comumente se entende como a "Mãe Natureza" operava no mundo dos homens segundo uma vontade própria. Nesse mesmo sentido, tal entidade, segundo Smith (2004, p. 184) afirma, tem "propósitos". Dentro deles, dois dos maiores seriam "a manutenção do indivíduo e a propagação da espécie"3. Dessa forma, para que conseguíssemos realizar essas duas grandes finalidades, a Natureza teria dotado os seres humanos com certos atributos. Essa é base para poder interpretar aquilo que Smith, da mesma forma que tantos outros, chamará de "natureza humana"4 que será o tema a seguir.

Diferente do que acontecia com sua ideia de "natureza humana" que era a mesma utilizada, por exemplo, por Platão e Aristóteles, Smith parte de uma concepção de natureza humana muito particular que o distancia de ambos os pensadores gregos ${ }^{5}$. Para Smith, todos os homens são, em maior ou menor medida, iguais: (a) todos os homens são, por natureza, impulsados a perseguir a riqueza, (b) todos sentem, por natureza, admiração pelos homens poderosos e ricos, (c) todos rejeitam, por natureza, a condição de pobreza etc. Ademais, ele entende que, em situações idênticas, a tendência é que os seres humanos experimentem os mesmos sentimentos morais. Concluindo, podemos afirmar que, para Smith, existe uma e só uma natureza humana. Essa ideia proposta na Teoria dos sentimentos morais se verá

\footnotetext{
${ }^{2}$ Em A Teoria dos sentimentos morais, conjuntamente com as reflexões sobre a natureza, Smith (2004, p. 212) chega a versar sobre a "diosa Fortuna que gobierna el mundo [y que] ejerce alguna influência allí donde no estaríamos dispuestos a permitirle ninguna", nos mesmos termos que Maquiavel. Porém, no caso de Smith, parece bastante claro que ele se serve da figura da deusa romana por motivos puramente estilísticos.

${ }^{3}$ O leitor da obra de Kant facilmente perceber a grande similitude da ideia de natureza utilizada por Smith com a ideia de natureza kantiana utilizada em Ideia de uma história universal com um propósito cosmopolita (KANT, 2008).

${ }^{4}$ Peço ao leitor para reparar no fato de que, ao falar sobre a Mãe Natureza, utilizo letra maiúscula, enquanto que quando falo da natureza humana - a qual se encontra no mesmo estado categorial que outras eventuais naturezas, tais como a natureza do gato ou da natureza do cachorro - utilizo letra minúscula.

${ }^{5}$ Tanto para Platão quanto para Aristóteles não existia uma única natureza humana. Basicamente, no caso de Platão (2011), salienta nos livros II, III e IV da República existiriam diferenças naturais entre as almas dos guardiães e dos artesãos, umas lideradas pela ração e as outras pelas paixões. Mais ainda, as almas de cada ser humano possuiria uma natureza específica e isso o dotava da capacidade de realizar alguns trabalhos melhor que o resto dos homens e o impedia de realizar certas tarefas com perfeição. No caso do Aristóteles (2004, p. 49-53), ele afirma que existe a diferença entre a natureza dos homens livres e dos escravos, tanto espiritual quanto física. Assim, em ambos os casos, nossos autores se servem do conceito de natureza humana para legitimar divisão social de suas sociedades.
} 
reforçada em A riqueza das nações. Para observar isso de forma nítida, vale a pena realizar a seguinte citação:

\begin{abstract}
Na realidade, a diferença de talentos naturais em pessoas diferentes é muito menor do que pensamos; a grande diferença de habilidade que distingue entre si pessoas de diferentes profissões, quando chegam à maturidade, em muitos casos não é tanto a causa, mas antes o efeito da divisão do trabalho. A diferença entre as personalidades mais diferentes, entre um filósofo e um carregador comum na rua, por exemplo, parece não provir tanto da natureza, mas antes do hábito, do costume, da educação ou formação. Ao viverem o mundo, e durante os seis ou oito primeiros anos de existência, talvez fossem muito semelhantes entre si, e nem seus pais nem seus companheiros de folguedo eram capazes de perceber nenhuma diferença notável. Em torno dessa idade, ou logo depois, começam a engajar-se em ocupações muito diferentes. Começa-se então a perceber a diferença de talentos, sendo que esta diferenciação vai-se ampliando gradualmente, até que, ao final, o filósofo dificilmente se disporá a reconhecer qualquer semelhança. [...] Muitos grupos de animais, todos reconhecidamente da mesma espécie, trazem de nascença uma diferença de "índole" muito maior do que aquela que se verifica entre as pessoas, anteriormente à aquisição de hábitos e à educação. Por natureza, a diferença entre um filósofo e um carregador de rua, no tocante ao caráter básico e à disposição, não representa sequer $50 \%$ da diferença que existe entre um mastim e um galgo, ou entre um galgo e um spaniel, ou entre este último e um cão pastor. (SMITH, 1983, p. 51)
\end{abstract}

Claro que, ao longo da Teoria dos sentimentos morais - e inclusive da Riqueza das

Nações - Smith aponta para diversos exemplos nos quais alguns indivíduos não se sentem atraídos pela riqueza, não sentem aversão pela pobreza etc. No entanto, nesses casos particulares e específicos, o autor manifesta claramente que o motivo desses desvios do comportamento natural do ser humano pode ser explicado a partir de causas não naturais, mas, estritamente sociais. Por tal motivo, coerente com sua ideia de uma natureza humana igual para todos os seres humanos, afirmara também a seguinte tese:

Essa ordem de coisas que a necessidade impõe de modo geral, ainda que nem sempre em um país específico, é reforçada em cada país pelas inclinações naturais do homem. Se as instituições humanas nunca tivessem interferido nessas inclinações naturais, jamais as cidades poderiam em qualquer parte ter crescido além da medida compatível com o aprimoramento e o cultivo do território ou o país do qual fazem parte [...] Além disso, a beleza do campo, os prazeres de uma vida campestre, a tranquilidade de espírito que ela proporciona, e, onde a injustiça das leis humanas não a perturbar, a autonomia que tal modalidade de vida assegura, possuem encantos que atraem praticamente a todos; e, assim como o cultivo do solo sempre foi o destino natural do homem, da mesma forma, em todos os estágios de sua existência, ele parece conservar uma predileção por essa ocupação primitiva. (SMITH, 1983, p. 322) 
A partir destas considerações, não cabe concluir que, para nosso autor, os homens são cópias exatas. Aliás, ao longo da Teoria dos sentimentos morais Smith avança teses sobre os sentimentos morais que nos falam de diferentes tipos de homens. No entanto, iluminados por suas considerações sobre a natureza humana na Riqueza das nações anteriormente citadas, podemos concluir que, para nosso autor, as grandes diferenças que existem entre diferentes sujeitos humanos não são "naturais", isto é, que elas não derivam da natureza ( $\varphi v ́ \sigma ı \varsigma)$ de cada um deles. Muito pelo contrário, os seres humanos compartilhariam uma mesma natureza humana e suas diferenças substantivas devem ser entendidas com base na sua formação, profissão, hábitos etc., isto é, a partir de fatores de ordem social e externo.

Finalmente, outra característica da concepção smithiana de ser humano também decisiva para sua proposta metaética é que, dado o fato de que todos os homens possuem uma única natureza humana, ele é previsível. Com base nesta percepção, ao longo da Teoria dos sentimentos morais, Smith postula uma grande quantidade de sentenças com esse tipo de fórmulas: "Se um homem é sábio então X". "Se o homem é tolo, então Y". "Quem fizer A, sentirá culpa". "Quem fizer B e for sábio, não se importará pela opinião dos outros e se gratificará por ter feito B”. Dessa forma, podemos dizer que, para Smith, a natureza humana não é uma caixa de Pandora. O ser humano é, ante tudo, um ser decifrável.

\subsection{Imaginação}

Uma das capacidades humanas que mais fora objeto de estudo na filosofia prémoderna e moderna é, certamente, a imaginação. Já na metade do século XVII, Hobbes (2005, p. 11) afirma que a imaginação opera somente com imagens contidas na nossa memória. Ela não seria outra coisa que trazer de volta à nossa mente aquelas coisas que já tinham sido captadas pelos nossos sentidos, seja de forma simples ou composta. Segundo Hobbes, nos valendo da nossa imaginação, podemos formar a partir das imagens de coisas que nunca vimos juntas, uma única imagem composta, por exemplo um centauro. A imaginação também representa um dos principais ingredientes dentro da teoria do conhecimento de muitos dos autores do sensibilismo escocês. No caso do seu maior expoente, David Hume (2011, 53), a imaginação possibilita não somente a construção de ideias complexas (cavalo virtuoso, montanha de ouro) a partir da combinação de ideias simples, senão também que o ser humano possa "imitar ou copiar percepções dos 
sentidos". Mais do que isso, a imaginação permite ao ser humano antecipar sensações. Seguindo essa tese humeana, o indivíduo pode experimentar uma sensação de estar se queimando de uma forma quase tão vívida como se seu corpo estivesse perto de uma fogueira que está a vários metros de si. Mas, se, para Hume, a imaginação representa uma forma de reproduzir sensações, para Smith ela terá um forte papel na ética - no comportamento - das pessoas e na esfera da moralidade. Ela representa, no marco de A teoria dos sentimentos morais, um dos mais importantes atributos da natureza humana e a base para a formulação de toda sua teoria ética. Ela é, entre outras coisas, condição para que o ser humano seja simpático.

\subsection{Simpatia}

Derivado do Grego ${ }^{6}(\sigma v v+\pi \alpha \dot{\alpha} \chi \chi)$, Smith começa a Teoria dos sentimentos morais versando sobre a capacidade do ser humano de sentir o mesmo sofrimento que outra pessoa ou outro ser está sofrendo. Segundo o autor, o fato de que os seres humanos somos simpáticos não precisa de demonstração; tanto homens virtuosos quanto viciosos são simpáticos. A simpatia, segundo Smith, faz parte da natureza do ser humano.

Como já foi adiantado, o ser humano pode ser simpático devido a que conta com a capacidade mental da imaginação. Sem imaginação não haveria possibilidade de que o homem sentisse a dor dos outros. Nos termos de Smith:

Como carecemos de la experiencia inmediata de lo que sienten las otras personas, no podemos hacernos ninguna idea de la manera en que se ven afectadas, salvo que pensemos cómo no sentiríamos nosotros en su misma situación. Aunque quien esté en el potro sea nuestro propio hermano, en la medida en que nosotros no nos hallemos en su misma condición nuestros sentidos jamás nos informarán de la medida de su sufrimiento. Ellos jamás nos han llevado ni pueden llevarnos más allá de nuestra propia persona, y será sólo mediante la imaginación que podremos formar alguna concepción de lo que son sus sensaciones. Y dicha facultad sólo nos puede ayudar representándonos lo que serían nuestras propias sensaciones si nos halláramos en su lugar. Nuestra imaginación puede copiar las impresiones de nuestros sentidos, pero no de los suyos. La imaginación nos permite situarnos en su posición, concebir que padecemos los mismos tormentos, entrar por así decirlo en un cuerpo y llegar a ser en alguna medida una misma persona con él y formarnos así alguna idea de sus sensaciones, e incluso sentir algo parecido, aunque con una intensidad menor. Cuando incorporamos así su agonía, cuando la hemos adoptado y la hemos hecho nuestra, entonces empieza a afectarnos, y

\footnotetext{
${ }^{6}$ Do ponto de vista etimológico, o termo "compaixão", derivado do Latim, possui o mesmo sentido.
} 
temblamos y nos estremecemos al pensar en lo que él está sintiendo. Así como el dolor o la angustia de cualquier tipo provocan una pena que puede ser enorme, el hacernos a la idea o imaginar que los padecemos suscita la misma emoción en algún grado, en proporción a la vivacidad o languidez de dicha concepción (SMITH, 2004, p. 49-50, grifo meu)

Neste trecho, podemos observar como Smith traduz a concepção humeana das ideias e das impressões humanas aos sentimentos morais. Se para Hume $(2000,2011)$ uma impressão é sempre mais forte que a ideia que ela gera, a concepção de simpatia smithiana segue a mesma regra: o ser simpático sente a mesma dor que o sujeito portador do sofrimento, contudo de forma menos intensa.

\subsection{Reconhecimento intersubjetivo, vaidade e inveja}

A partir das reflexões smithianas sobre a simpatia, sabemos que, se valendo da imaginação, os homens podem se colocar na posição dos outros. Todavia, a imaginação também permite ao agente saber qual é a percepção que os outros homens membros da sua sociedade possuem dele e de suas ações, se colocando na posição de um observador externo, isto é, de outro indivíduo. Assim, dado que ele sente um forte desprezo por algumas ações realizadas por outros homens, ele pode deduzir que, caso ele pratique as mesmas ações, será igualmente desprezado pelos outros. Dessa forma, ele pode concluir se as outras pessoas ao seu redor, prima facie, aprovariam determinadas ações suas ou não ${ }^{7}$. Sendo assim, a opinião das outras pessoas adquire uma grande importância para a compreensão do comportamento do ser humano, dado que todos os agentes morais possuiriam, por natureza, a inclinação de ajustar seus atos segundo a opinião dos outros membros da sua sociedade. Trata-se de uma explicação naturalista da ideia de reconhecimento intersubjetivo, que será desenvolvida de

\footnotetext{
${ }^{7}$ Essa mesma capacidade natural de poder imaginar se os outros membros da sociedade aprovam nosso agir será a condição básica para o maior elemento da ética smithiana, qual seja, o experimento mental do observador imparcial. Para Smith, a imaginação, além de permitir ao ser humano se colocar de forma fictícia na pele do outro, também permite ao ser humano se colocar na posição de um ser fictício, de um outro não real desde o qual julgar as próprias ações. Dessa forma, fazendo uso da imaginação, o indivíduo consegue se desdobrar e, assim, responder uma bateria de perguntas. Segundo Smith, observador imparcial consiste no exercício mental que a pessoa realiza toda vez que quer saber qual o grau de correção das suas ações. Uma vez realizada uma determinada ação ou mesmo antes de executá-la, nos realizamos os seguintes questionamentos: Qual seria a percepção que um observador imparcial teria perante meu agir? Quais seriam os sentimentos morais experimentados por um observador imparcial que tivesse presenciado minha ação? Um observador imparcial aprovaria a minha ação? Em resumo, trata-se do procedimento a partir do qual o sujeito, se valendo de sua imaginação, pode construir na sua mente os sentimentos de um agente externo fictício e, dessa forma, julgar moralmente seu agir. Porém, como já foi adiantado anteriormente em nota de rodapé, devido aos objetivos do presente trabalho, não realizarei uma análise detalhada deste procedimento ético.
} 
uma forma mais acabada só a partir do idealismo alemão de cunho hegeliano ${ }^{8}$. O sujeito, fazendo uso da sua imaginação, tende a realizar aquelas ações que seriam aprovadas pelos outros. O motivo é o desejo de todo homem de ser reconhecido pelos seus pares como um alguém destacado dentro da sociedade.

Pode se sustentar que, segundo a concepção smithiana de natureza humana, todo sujeito é inclinado a agir visando sempre uma escala de valores que, grosso modo, compartilha com seus pares. Em outras palavras, o homem, por natureza, tende a agir com base no desejo de que suas ações sejam aprovadas pelos outros. No entanto, isso não equivale a dizer que Smith considera que o homem esteja sempre preocupado com o bem-estar e a felicidade dos outros. Utilizando um exemplo smithiano, podemos dizer que se um aristocrata quer "brilhar num baile" (SMITH, 2004, p. 130), não se deve a que ele quer que as outras pessoas sintam prazer estético ao vê-lo dançar, senão a que, basicamente ele quer que as outras pessoas apreciem, aprovem e até bajulem suas roupas finas e caras, assim como seu característico comportamento nobre. "Deseamos ser respetados y respetables" (SMITH, 2004, 136, grifo meu). Na direção contraria, o oposto também se aplica, dado que "[s]i, por el contrario, percibimos que somos objetos naturales del disgusto, cualquier muestra de su desaprobación nos mortifica enormemente" (SMITH, 2004, p. 223, grifo meu). Dados esses postulados, o sentimento que move as pessoas que estão numa situação favorável dentro da sociedade a se comportar dessa forma, longe de ser o interesse pelo bem-estar dos outros, é a "vaidade" (SMITH, 2004, p.122-ss). E é essa vaidade dos ricos e poderosos que gera a inveja daqueles que, por falta de poder e riqueza, não podem ser vaidosos. Vaidade e inveja serão dois grandes sentimentos que servem, segundo Smith, para compreender a natureza humana e o que o próprio Smith chama de "corrupção dos sentimentos morais".

\subsection{Smith e a corrupção dos sentimentos morais}

\footnotetext{
8 "Si fuera posible que una criatura humana pudiese desarrollarse hasta la edad adulta en un paraje aislado, sin comunicación alguna con otros de su especie, le sería tan imposible pensar en su propia personalidad, en la corrección o demérito de sus sentimientos y su conducta, en la belleza o deformidad de su mente, como en la belleza o deformidad de su rostro. Todos ellos son objetos que no es fácil que vea, que naturalmente no observa, y con respecto a los cuales carece de un espejo que los exhiba ante sus ojos. Pero al entrar en sociedad, inmediatamente es provisto del espejo que antes le faltaba" (SMITH, 2004, p. 222, grifo meu). Como sabemos a partir da Filosofia do Direito, Hegel (2000) foi um ávido leitor da obra econômica de Smith. A influência de Smith sobre Hegel torna-se clara ao observar as considerações que o autor alemão realizou sobre as corporações da sociedade civil. Para um aprofundamento neste tópico, veja Herzog (2013). Já no terreno da ética, a teoria do reconhecimento de cunho hegeliana possui também uma grande dívida com Smith, um assunto que ainda não foj suficientemente explorado e que certamente não poderei explorar no presente trabalho.
} 
Como já foi salientado, Smith começa A teoria dos sentimentos morais versando sobre a simpatia, isto é, a capacidade natural do ser humano de sentir a dor de outros seres humanos, animais. No começo da obra, o conceito de simpatia segue de forma estrita o sentido etimológico do termo. Não obstante, nos parágrafos 1 e 2 da Seção III da parte 1, Smith ampliará o uso desse conceito. Ele deixará de entender a simpatia como a mera capacidade de sentir a dor de outros de uma forma menos intensa. Ele manifestará que a mesma capacidade que nos permite sentir a dor alheia nos permite, ao mesmo tempo, experimentar a alegria de outros seres humanos, isto é, que quando alguém "brilha no baile", nós podemos sentir, mesmo que de forma menos intensa, o prazer que aquele sujeito sente por poder alimentar sua vaidade. A partir desse novo conceito de simpatia, Smith avança a tese de que os homens são mais simpáticos em relação aos ricos e poderosos que com os pobres. Ele dirá:

Cuando pensamos en la vida de los personajes eminentes, con esos engañosos colores con que la imaginación propende a pintarla, parece ser casi la idea abstracta de un estado perfecto y feliz. Es el mismo estado que en todas nuestras fantasías y ociosas ensoñaciones hemos diseñado para nosotros mismos como el objeto último de todas nuestras aspiraciones. Sentimos por ello una simpatía peculiar hacia la satisfacción de aquellos que lo han logrado. Aplaudimos todos sus gustos y compartimos todos sus deseos. ¡Qué lástima - pensamos si alguna cosa pudiese estropear y arruinar un marco tan placentero! Podemos incluso ansiar que fuesen inmortales y nos parece riguroso que la muerte deba a la postre poner término a un disfrute tan cabal. Nos parece cruel que la naturaleza los empuje desde sus exaltadas posiciones hasta ese hogar humilde, aunque hospitalario que ha previsto para todos sus hijos. ¡Vida eterna al gran rey! Tal el aludo que el estilo oriental de la adulación, estaríamos prestos a pronunciar si la experiencia no nos advirtiese sobre lo absurdo que resulta. Cada calamidad que les sobreviene, cada injuria que sufren excita en el corazón del espectador diez veces más compasión y resentimiento que los que habría sentido si las mismas cosas les hubiesen acaecido a otras personas. (SMITH, 2004, p. 124-5)

A partir deste postulado, o perfil do texto de Smith muda desde uma mera descrição da natureza humana, para um tom mais crítico. Se no começo Smith afirmava que o ser humano era, por natureza, simpático, e que o ser humano podia experimentar na sua própria pele a dor dos outros via imaginação, a partir de agora a ênfase estará dada no fato de que essa simpatia natural é fortemente seletiva e que ela se manifesta de forma mais ou menos intensa de acordo com a posição social da pessoa pela qual o agente simpatiza. Em outras palavras, se bem o ser humano pode experimentar, através da imaginação, a dor e a alegria que outro ser humano experimenta, para nosso autor, existe no homem a tendência de ser mais 
sensível ao sofrimento e à alegria dos ricos e poderosos. Isso, para Smith, constitui a principal fonte de corrupção de nossos sentimentos morais. Nas suas palavras:

Esta disposición a admirar y casi idolatrar a los ricos y poderosos, y a despreciar o como mínimo ignorar a las personas pobres y de modesta condición, aunque necesaria para establecer y mantener la distinción de rangos y el orden, es al mismo la mayor y más extendida causa de corrupción de nuestros sentimientos morales. (SMITH, 2004, p. 136, grifo meu)

Essa corrupção de sentimentos morais se manifesta de diversas formas. (1) A primeira delas é o fato de que os homens procuram a riqueza e poder acima de tudo - sossego, paz, prazer, ócio, sabedoria etc. Isso acontece tanto nas classes baixas quanto entre os poderosos. A respeito do primeiro caso, diz Smith:

¿Cuál es el fin de la avaricia y la ambición, de la persecución de riquezas, de poder, de preeminencia? ¿Es porque han de satisfacerse las necesidades naturales? El salario del más modesto trabajador alcanzaría. Su retribución le permite conseguir alimento y vestido, el bienestar de una casa y una familia. Si examinamos con rigor su economía, comprobaremos que gasta una parte apreciable de sus ingresos en comodidades que cabría calificar de superfluas, y que en contextos extraordinarios incluso asigna una fracción a la vanidad y la distinción. (SMITH, 2004, p. 122)

Smith, em claro alinhamento com a posição de Aristóteles (1988) sobre a crematística, avança uma crítica ética da pleonexia humana, do desejo absurdo de acumular bens supérfluos, da irracionalidade do desejo de conquistar sempre novas riquezas. Na mesma direção, ele se posiciona contra o típico empreendedorismo burguês e seu desejo irrefreável de riqueza.

El hijo del pobre [...] encuentra que la cabaña de su padre es demasiado pequeña para él y fantasea con que debería vivir más cómodamente en un palacio. [...] En su fantasía parece la vida de unos seres superiores, y para alcanzar esa meta se dedica para siempre a la búsqueda de la riqueza y los honores. Para acceder a las comodidades que esas cosas deparan se somete en el primer año de su empresa, es más, durante el primer mes, a mayores fatigas corporales y mayor desasosiego espiritual que los que habría sufrido en toda su vida si no las hubiese ambicionado. [...] Durante toda su vida lucha por la idea de un reposo artificial y elegante que quizá nunca consiga, pero en aras del cual sacrifica una tranquilidad real que está siempre a su alcance, y si finalmente en su extrema vejez lo logra, descubrirá que desde ningún punto de vista es preferible a la modesta seguridad y contento que abandonó por él. (SMITH, 2004, p. 319-20) 
Em relação ao segundo caso, falando sobre a estima natural do homem de status, ele agrega:

Esto es lo que, a pesar de las limitaciones que impone, a pesar de la pérdida de libertad que entraña, convierte a la grandeza en objeto de envidia, y compensa, en opinión de los seres humanos, todo el esfuerzo, la angustia y las humillaciones que deben superarse en su búsqueda; y también, lo que es aún de mayor importancia, todo el ocio, el sosiego y la despreocupación que se pierden para siempre con su adquisición. (SMITH, 2004, p. 124, grifo meu)

Smith também incorre em um dos seus tantos exemplos envolvendo reis. Ele comenta:

Cuando el rey llegó al final del relato ordenado de todas las conquistas que se proponía acometer, el favorito preguntó: «¿Qué hará Su Majestad a continuación?». El monarca respondió: «Me divertiré entonces con mis amigos y lo pasaremos bebiendo en buena compañía». A lo que el favorito replicó: «¿Y qué le impide a Su Majestad hacer eso ahora?». (SMITH, 2004, p. 269-70)

(2) Uma segunda forma em que essa corrupção dos sentimentos morais se manifesta tem lugar com uma inversão de valores - uma transvaloração - a partir da qual os homens passam a desestimar as grandes virtudes humanas e passam a reverenciar as qualidades próprias dos ricos; os sábios são desestimados e as idiotices dos ricos são aplaudidas.

[U]na vez en el mundo, pronto nos percatamos de que la sabiduría y la virtud no son en absoluto los únicos objetos del respeto, como el vicio y la estupidez tampoco lo son del menosprecio. Con frecuencia vemos cómo las atenciones más respetuosas se orientan hacia los ricos y los grandes más intensamente que hacia los sabios y los virtuosos. (SMITH, 2004, p. 136)

(3) Outra forma a partir da qual a corrupção dos sentimentos morais se manifesta é a comum falta de sensibilidade pelo sofrimento dos pobres. Ele afirma: "A menudo observamos que los vicios y tonterías de los poderosos son mucho menos despreciados que la pobreza y fragilidad de los inocentes" (SMITH, 2004, p. 136-7). "La paz y el orden de la sociedad son incluso más importantes que el alivio de los desdichados" (SMITH, 2004. P. 395).

(4) Finalmente, uma última forma na qual, segundo nosso autor, essa corrupção dos sentimentos morais se manifesta é a partir da popular consideração dos poderosos como nossos “superiores naturais" (SMITH, 2004, 127, grifo meu). 
La doctrina de la razón y la filosofía es que los reyes son servidores del pueblo, a ser obedecidos, resistidos, depuestos, o sancionados según demanda la conveniencia pública; pero no es la doctrina de la naturaleza. La naturaleza nos instruye para que nos sometamos a su voluntad, temblemos y nos postremos ante su eminencia, consideramos su sonrisa como retribución suficiente para compensar cualquier servicio, y temamos su descontento, aunque ningún otro mal se derive de él, como la humillación más severa. (SMITH, 2004, p. 126)

Para retratar esse aspecto da natureza humana, Smith se serve do eminente caso de Luís XIV da França e de um acontecimento peculiar da sua biografia narrado por Voltaire, autor que Smith conhecera pessoalmente em solo francês.

Luís XIV, durante la mayor parte de su reinado, fue considerado no sólo en Francia sino en toda Europa como el modelo más perfecto de un gran príncipe. ¿Pero cuáles fueron los talentos y virtudes merced a los cuales adquirió una buena reputación?, ¿fueron acaso sus amplios conocimientos, su juicio exquisito su heroico valor? Nada de eso. Pero fue ante todo el príncipe más poderoso de Europa y ostentó por ello el rango más elevado éntrelos reyes; y su historiador relata que sobrepasaba a todos sus cortesanos en el donaire de su figura y la majestuosa belleza de su aspecto. El sonido de su voz, noble y afectuosa, ganaba los corazones que su presencia intimidaba. Tenía un paso y un porte que sólo encajaban con él y su rango, y que habrían resultado ridículos en otra persona. La turbación que suscitaba en aquellos que le hablaban halagaba esa satisfacción secreta con la que se sentía su propia superioridad. El viejo oficial, confundido y aturdido al solicitarle un favor, que no fue capaz de terminar su discurso y le dijo: "Señor, espero que $\mathrm{Su}$ Majestad no crea que tiemblo así ante sus enemigos", no tuvo dificultades en obtener lo que deseaba». (SMITH, 2004, 128) ${ }^{9}$

A ideia smithiana segundo a qual acontece na natureza humana uma corrupção dos sentimentos morais representa uma navalha de dois gumes. Em primeiro lugar, ela supõe que os agentes morais vejam seus sentimentos morais corrompidos pela alta valorização que eles têm da riqueza e do poder. No entanto, como já foi adiantado no começo, Smith se serve de

\footnotetext{
${ }^{9}$ Adam Smith tem sido ao longo da história um ícone da filosofia e da economia clássica que foi historicamente considerado entre os pensadores liberais burgueses como um liberal radical. Trata-se de uma leitura tendenciosa do autor que tende a enfatizar os elementos mandevilleanos da sua obra, cuja existência é impossível de negar. Porém, A Teoria dos sentimentos morais nos permite observar que existem elementos no trabalho de Smith que o colocam mais próximo de pensadores de perfil mais revolucionário, que do próprio Mandeville e sua escola de pensamento. Isso não somente devido às passagens nas quais Smith $(2004$, p. 520-ss) se posiciona diametralmente contra as teses mandevilleanas sobre o vício e a virtude, mas também a partir de elementos como os acima analisados. Com o exemplo de Luís XIV e seu oficial e com sua ideia de ordem social baseada na corrupção dos sentimentos morais das pessoas, Smith aponta para o fato de que, via de regra, nós seres humanos, somos governados por pessoas ridículas, pessoas que, por sinal, reverenciamos, bajulamos e até consideramos como sendo nossos governantes por natureza. Nos tempos de Smith, seria possível fazer uma afirmação desse tipo no marco de uma Inglaterra que um século atrás tinha, com sua Revolução Gloriosa, sabido acabar com as pretensões absolutistas da Casa Stuart ou na França da debilitada coroa de Luís XVI. Porém, esse tipo de afirmação, clara portadora do germe revolucionário, bem poderia custar muito caro a um autor em solo alemão ou espanhol.
} 
uma concepção de Natureza pré-darwiniana e com grandes pontos em contato com as concepções mais rudimentares da Grécia clássica e pós-clássica. Trata-se de uma natureza volitiva, que imprime na natureza humana certos atributos com base nos seus objetivos maiores. Assim, nossos sentimentos morais deveriam ser de uma forma, mas acabam sendo de outra, e isso acontece com base num propósito da Natureza, a saber, a ordem social. Em outras palavras, "el sentir mucho por los demás y poco por nosotros mismos, el restringir nuestros impulsos egoístas y fomentar los benevolentes, constituye la perfección de la naturaleza humana" (SMITH, 2004, p. 74-5, grifo meu). Porém,

[1]a naturaliza ha sido prudente al dictaminar que la distinción entre rangos, la paz y el orden de la sociedad, descansaran con más seguridad sobre la nítida y palpable diferencia de cuna y fortuna que sobre la invisible y muchas veces incierta diferencia de sabiduría y virtud. Los ojos incriminadores de la gran muchedumbre de seres humanos pueden percibir claramente la primera, pero sólo con dificultad el esmerado discernimiento de los sabios y virtuosos puede detectar adecuadamente la segunda. La benevolente sabiduría de la naturaleza es igualmente evidente en la ordenación de todas esas preferencias. (SMITH, 2004, p. 395-6) ${ }^{10}$

Nesse quadro acima descrito, a corrupção dos sentimentos morais é entendida como a forma em que a natureza busca alcançar a ordem social, ordem que acabará colocando os ricos no poder e submetendo os pobres à vontade dos poderosos.

Concluo assim a primeira parte do artigo, em que apresentei alguns dos elementos centrais da teoria ética smithiana. A seguir, conforme o estipulado, passo a analisar os primeiros passos de Friedrich Engels como intelectual, tentando estabelecer pontes entre suas considerações éticas de juventude a teoria dos sentimentos morais de Adam Smith.

\section{O JOVEM ENGELS E O CARATER MORALISTA DA SUA CRÍTICA DA ECONOMIA POLÍTICA}

Em 1844, o filósofo alemão Friedrich Engels, viaja desde sua moradia em Manchester até Paris para negociar a publicação do seu mais recente artigo nos Anais Franco-Alemães. Dessa vez, tratava-se do seu trabalho intitulado Para a crítica da Economia Política. Sua tratativa bem-sucedida para a publicação do referido trabalho sacramentaria a aproximação

\footnotetext{
${ }^{10}$ Como já adiantei no começo do presente texto, a ideia smithiana de uma Mãe Natureza volitiva que impõe um vício na natureza do ser humano com base em propósitos maiores guarda uma forte similitude com a ideia kantiana de sociabilidade insociável (KANT 2008).
} 
pessoal e intelectual de Marx e Engels pelo resto de suas vidas ${ }^{11}$. Mais que isso, aquele curto artigo conta com o grande mérito de ter servido de faísca inspiradora para a nova fase de Marx como filósofo. Ele, que até então, além de escrever alguns pequenos artigos sobre a situação política dos Estados sob domínio prussiano e outros trabalhos menores, tinha seguido à risca os passos dos jovens hegelianos e se dedicado quase exclusivamente a estudar as obras de Hegel e Feuerbach, após sua aproximação com Engels, passará a estudar menos Idealismo Alemão e mais Economia Política. Dessa forma, os estudos de Marx de 1842 e 1843 sobre a Filosofia do Direito de Hegel e a crítica da religião de Feuerbach ${ }^{12}$ seriam, em 1844, sucedidos por um aprofundamento exaustivo das obras de Adam Smith e David Ricardo, entre outros representantes da teoria econômica inglesa ${ }^{13}$. Em resumo, e parafraseando Kant, o artigo de Engels teria despertado Marx do seu "sono dogmático". Quinze anos mais tarde, Marx, na sua Contribuição à crítica da Economia Política, dirá a respeito desse trabalho que se tratava de um "genial esboço de uma crítica das categorias econômicas" (MARX, 2008, p. 49, grifo meu). Neste item, exponho algumas das teses mais destacadas do artigo do jovem Engels, tendo por objetivo apontar para o perfil desse trabalho e os eventuais elementos smithianos que nela apareçam.

\subsection{Para a crítica da Economia Política: primeiras reflexões éticas do jovem Engels}

Em 1842, Engels conhece quem teria conduzido os intelectuais reformistas berlinenses ao comunismo, o Professor Mosses Hess. Esse evento marca o início do contato direto de Engels com a teoria do comunismo do seu país. Ademais, nesse mesmo ano, na sua mudança para Manchester, Engels se aproximaria da obra de Robert Owen (1813) e do florescente movimento cartista. A consideração desses fatos serve para entender por que os primeiros passos de Engels como crítico da Economia Política possuem um claro perfil moralista.

Em janeiro de 1844, o jovem Engels tinha apenas 23 anos quando consegue finalmente publicar um curto artigo nos Anais Franco-Alemães. Nele, ele manifestará expressamente sua

\footnotetext{
${ }^{11}$ Engels teria conhecido a Marx em 1842, na sua primeira tentativa de publicar um artigo na Gazeta Renana, jornal de perfil liberal no qual Marx trabalhava por aqueles anos. No entanto, o primeiro contato entre ambos os autores não teria sido bem-sucedida, dado que o jovem Marx reprovava aqueles críticos radicais que colocavam em risco a estabilidade do periódico, dentro dos quais incluía a Engels. Porém, em 1844, Marx e Engels dariam começo a uma amizade pessoal que duraria até o último dia de vida de Marx. Realizar uma abordagem exaustiva da bibliografia de ambos os autores vai muito além dos objetivos do presente trabalho.

${ }^{12}$ Anos dos quais datam A questão judaica (MARX, 2010), a Crítica da Filosofia do Direito de Hegel (MARX 2011a) e a Crítica da Filosofia do Direito de Hegel - Introdução (2011a).

${ }^{13}$ Ano da escritura dos Manuscritos de 1844 (MARX, 2014a).
} 
simpatia tanto pelo socialismo inglês e pela proposta cooperativista e anticapitalista de Fourier e, coerente com tal inclinação, colocará em cheque a moralidade das principais pilares do sistema capitalista, com frases categóricas. Ele defenderá a tese de que "[a] nova economia, o sistema do livre comércio, apoiado na Wealth of nations, de Adam Smith, revelase como a hipocrisia, a imoralidade e a inconsequência que, presentemente, afrontam todos os domínios da liberdade humana" (ENGELS, 1979, p. 3, grifo meu). Dessa forma Engels se perfila para criticar as relações econômicas do seu tempo desde uma ótica puramente moralista. Assim, a respeito do comércio, ele afirma:

Cada compra e venda colocam frente a frente dois homens com interesses absolutamente opostos. Este conflito se funda numa considerável hostilidade, porque cada um conhece as intenções do outro e sabe que se opõem às suas. A primeira resultante deste fato é, por um lado, a desconfiança recíproca e, por outro, a justificação desta desconfiança, que utiliza meios imorais para impor um fim que não lhe fica atrás. É assim, por exemplo, que o primeiro princípio do comércio é ocultar ou dissimular tudo o que se possa diminuir o valor do artigo posto a venda. Resultado; no comércio é permitido tirar o maior partido da ignorância e da confiança da outra parte interessada, atribuindo à mercadoria à venda propriedades que ela não possui. Numa palavra: o comércio é a burla legal. Qualquer comerciante, se honrar a verdade, testemunhar-me-á que a prática confere com esta teoria. (ENGELS, 1979, p. 5, grifo meu)

Ato seguinte, Engels (1979, p. 5, grifo meu) afirma com todas as letras que o comércio possui uma "essência imoral". Apelando explicitamente para a obra smithiana, ele continua na mesma linha de raciocínio, apontando mais uma vez para a imoralidade do comércio nos seguintes termos:

Smith tinha razão ao elogiar a humanidade do comércio. Nada no mundo é absolutamente imoral; o próprio comércio, por um lado, presta homenagem à moralidade e à humanidade. Mas que homenagem! A lei do mais forte [...]. Esta é a humanidade do comércio, e esta maneira hipócrita de desviar a moralidade para fins imorais é o orgulho do sistema do livre comércio. (ENGELS, p. 6)

Engels não limita sua crítica moralista simplesmente ao comércio no marco do sistema econômico imperante na sua época. Ele também a estende para os proprietários fundiários, descrevendo o ato da apropriação da terra e seu posterior arrendamento como um grande roubo. 
O proprietário fundiário não tem nada a reprovar no comerciante. Ele rouba, ao monopolizar a terra. Ele rouba ao explorar o acréscimo populacional que aumenta a concorrência e, com isso, o valor da sua propriedade fundiária; rouba fazendo daquilo que não é produto da sua atividade pessoal, e que possui apenas por acaso, a fonte seu lucro particular. Rouba quando aluga, porque, no fim das contas, arroga-se os melhoramentos feitos pelo rendeiro. [...] Antes de nos colocarmos a nós mesmos em leilão, havia que vender a terra, a terra que é tudo para nós, a condição primeira da nossa existência; isso foi e é até hoje uma imoralidade, só ultrapassada pela alienação de si mesmo. ${ }^{14}$ (ENGELS, 1979, p. 11)

Finalmente, Engels destina, nesse seu primeiro artigo sobre Economia Política, algumas linhas para criticar o caráter imoral do papel desenvolvido por mais um agente destaque dentro das relações de produção capitalistas, a saber, o especulador da Bolsa.

O especulador conta sempre com os acidentes, particularmente com as más colheitas; ele utiliza tudo, como, por exemplo, à época, o incêndio de Nova York; o ponto culminante da imoralidade é a especulação na Bolsa, pela qual a história e, nela, a humanidade, são assimiladas ao conjunto dos meios próprios para satisfazer a cupidez do especulador calculista ou felizardo. (ENGELS, 1979, p. 15)

A partir da sua crítica moral aos pilares das relações de produção capitalista, o jovem Engels oferece elementos para condenar o sistema como um todo, sistema que estaria do princípio ao fim corrompido pelas ações imorais de muitos dos seus principais agentes. Porém, cabe destacar que, nesse trabalho, Engels emerge como intelectual realizando uma crítica desses agentes, puramente circunscrita ao marco da moralidade. O jovem pensador ainda não dominava, nem de perto, as ferramentas intelectuais para realizar uma crítica mais aprofundada das complexas relações de produção do sistema econômico da sua época. Quando Engels escrevia estas linhas, ainda não possuía, por exemplo, o conhecimento pleno e a clareza das ações daquela classe que Marx (2011. p. 97) chamará posteriormente nos Grundrisse de "estamento mercantil". Mesmo tendo lido as colocações de Smith a respeito do surgimento dos burgos, do florescimento do comércio e do mercado mundial etc., ele ainda não tinha, por exemplo, chegado à conclusão de que foram os comerciantes os primeiros que, se transformando em contratantes (Verleger) de mão de obra qualificada para a produção de têxteis, revolucionaram as relações de produção feudais para, assim, alavancar o surgimento

\footnotetext{
${ }^{14}$ Cabe remarcar que, muitos anos antes que Marx (2013a) escrevesse o famoso capítulo 24 do primeiro Capital I sobre a acumulação originária, Engels $(1979$, p. 11) já teria refletido sobre esse polémico assunto tão caro da economia política inglesa.
} 
das relações de produção capitalistas ${ }^{15}$. O mesmo pode ser dito em relação a seu conhecimento sobre a Bolsa e outras complexas ações do sistema capitalista. Sendo assim, o alcance de seu primeiro trabalho não vai além do que podia ser esperado: trata-se de uma crítica das complexas relações de produção capitalistas em termos estritamente moralistas.

\subsection{Reflexões éticas em $A$ situação da classe trabalhadora na Inglaterra}

Segundo o que já foi dito, o jovem Engels de finais de 1844 e começos de 1845 era um emergente comunista. Dito isso, por essa data, ele padecia o conflito moral de (1) pertencer a uma família cristã-prussiana conservadora dedicada aos negócios da próspera indústria têxtil inglesa e, ao mesmo tempo, (2) simpatizar com o movimento cartista. Os registros desse malestar têm lugar na correspondência que ele manteve com Marx por aquela época. Assim, numa missiva datada em 20 de janeiro de 1845, ele comenta ao seu amigo:

É repugnante ser não apenas burguês, mas ainda industrial, ou seja, um burguês que participa ativamente da exploração do proletariado. Uns dias na fábrica do meu pai foram suficientes para convencer-me de que tudo isto é asqueroso. [...] A verdade é que um comunista pode levar, externamente, uma vida de burguês e ganhar dinheiro, desde que não escreva; mas é impossível dedicar-se, ao mesmo tempo, à propaganda comunista e aos ganhos e à indústria. (ENGELS, 1845 apud NETO, 2013, p. 12)

$\mathrm{Na}$ época em que Engels escrevia estas linhas para seu amigo, ele estava em pleno processo de produção de sua grande obra de juventude. Nela, ele exibirá maiores habilidades na escrita do que tinha demonstrado em seu primeiro artigo; pouco mais de um ano bastou-lhe para moderar muitas das suas afirmações a respeito da imoralidade das relações de produção burguesas e, também, mudar o perfil da crítica. No seu livro A situação da classe trabalhadora na Inglaterra, livro consagrado a analisar as péssimas condições materiais de vida dos trabalhadores das grandes fábricas e minas britânicas, ele reafirmará sua posição crítica em relação ao sistema de produção capitalista, porém desde um enfoque menos visceral e com um perfil mais científico. Mas o fato mais curioso é que, nesse novo livro, ele não versará sobre os agentes econômicos que o tinham ocupado no seu primeiro artigo. Ele deixará de lado a realização de acusações tão categóricas sobre a imoralidade do comércio, do proprietário fundiário e do operador da Bolsa, para focar sua atenção quase

\footnotetext{
${ }^{15}$ Será o próprio Engels quem num dos últimos textos por ele publicados (2017, 965-ss), reproduzirá essa tese nos termos marxianos acima expostos.
} 
exclusivamente na situação dos proletários ingleses e sua conflitiva relação com os capitalistas. Assim, pela primeira vez, Engels dirigirá sua atenção para as duas grandes classes em tensão apontadas futuramente pela teoria marxista. Será nesse marco de análise da situação da classe proletária inglesa que surgiriam suas teses severamente críticas sobre a moralidade burguesa, as quais passo a enunciar.

Engels afirmava explicitamente que a burguesia - concretamente, a burguesia inglesa - era imoral. Nas suas palavras:

Desconheço uma classe tão profundamente imoral, tão incuravelmente corrupta, tão incapaz de avançar para além do seu medular egoísmo como a burguesia inglesa - e penso aqui a burguesia propriamente dita, em particular a liberal, empenhada na revogação das leis sobre os cereais. Para ela, o mundo, (inclusive ela mesma) só existe em função do dinheiro; sua avidez se reduz a conseguir dinheiro; a única felicidade de que desfruta é ganhar dinheiro rapidamente e o único sofrimento que pode experimentar é perdê-lo. Essa avidez, essa sede de dinheiro impede a existência de quaisquer manifestações do espirito humano que não estejam maculadas por ela. (ENGELS, 2013, p. 307, grifo meu)

Engels inclusive especifica de forma muito nítida a que tipo de imoralidade está se referindo. Assim, ele agrega:

É certo que os burgueses da Inglaterra são bons maridos e pais de família, possuem aquilo a que se chamam virtudes privadas e, nas relações cotidianas, parecem tão respeitáveis e honestos quanto todos os outros burgueses - aliás, até mesmo nos negócios, é melhor tratar com eles que com os burgueses alemães, já que não são cavilosos e matreiros como nossos comerciantes. Mas tudo isso está subordinado, em última instância, ao que sempre é decisivo: seu interesse privado e, especificamente, sua obsessão de ganhar dinheiro. [...] Ao burguês da Inglaterra não lhe causa mossa que seus operários morram ou não de fome, desde que ganhe dinheiro. (ENGELS, 2013, p. 307-8, grifo meu)

Trata-se de uma crítica moral que visa apontar para a insensibilidade da classe burguesa $^{16}$ em relação aos pesares da classe operária, o que não é outra coisa que uma

\footnotetext{
${ }^{16}$ Engels deixa claro que sua crítica não é contra pessoas individualmente, mas contra o agir imoral de toda uma classe. Ele aponta explicitamente para o fato de que a burguesia inglesa como um todo é imoral devido a que, acima de tudo, somente pensa em ganhar dinheiro e, dessa forma, desconsidera o profundo mal-estar que ela, como classe dominante, impõe a classe proletária. Sendo assim, a imoralidade burguesa é coletiva, dado que nosso autor não critica alguns burgueses em particular, mas a burguesia como um todo. Tanto é assim que, na edição de 1887, Engels (2013, p. 324) acrescentou uma nota de rodapé na qual afirmava: "Para evitar interpretações equívocas e objeções impertinentes, quero sublinhar que sempre me referi à burguesia como classe e que os exemplos a que recorri, trazendo à colação indivíduos isolados, servem-me apenas como documentos do pensar e do agir dessa classe". Esse será o mesmo espírito a partir do qual Marx escreve sua obra prima. No Posfácio da segunda edição do Capital I, ele observa: "De modo algum retrato com cores róseas as figuras do capitalista e do proprietário fundiário. Mas aqui só se trata de pessoas na medida em que ela
} 
verdadeira, parafraseando Smith, "corrupção dos sentimentos morais”. Em outras palavras, a imoralidade burguesa apontada por Engels denuncia o fato de que os burgueses de sua época não conseguem sentir qualquer tipo de pesar ao ver os proletários sentirem dor ou inclusive agonizar até a morte; o burguês é indiferente ao sofrimento proletário. A corrupção moral da classe burguesa não estaria diretamente associada ao fato deles usarem proletários como meios para obter lucro, mas pelo fato de que sua ânsia constante de lucro inibiu sua capacidade de sofrer pela dor do outro ou, mais do que isso, poder sentir a dor do outro na própria pele. É nesse momento onde as considerações morais engelsianas evidenciam pontos em contato com a teoria ética smithiana, especialmente na sua ideia de "corrupção dos sentimentos morais".

A partir da anterior reflexão sobre os postulados morais engelsianos, podemos observar como o jovem pensador não rejeita, porém não adere à teoria ética kantiana. É claro que os postulados morais do jovem Engels não entram em momento nenhum em contradição com a teoria ética kantiana. Em ambos os casos, por exemplo, a exploração de proletários, evidencia, no primeiro caso, e supõe, no segundo, a presença de um elemento imoral. Porém o foco de ambas as propostas éticas é diferente. No caso de Kant (2007), a sensibilidade da pessoa não está em jogo. Para ele, o ato imoral acontece quando o agente moral, por exemplo, instrumentaliza outro ser humano, isto é, quando ele não é tratado como fim em si mesmo. Mas em momento nenhum Kant coloca em questão a capacidade da pessoa simpatizar com os outros seres humanos, isto é, a capacidade de sentir a dor do outro. Embora o elemento deontológico da ética kantiana lhe imprima um caráter em essência internalista e que dentro dessa posição internalista, o agente moral deve, entre outras coisas, refletir sobre a possibilidade de sua máxima de ação poder ser considerada como lei prática universal, o que caracteriza o ato imoral no marco dela não está associado à sensibilidade do agente moral e à sua eventual capacidade de se colocar, parafraseando mais uma vez Smith, se colocando na pele do outro. No caso kantiano, a imoralidade tem lugar quando o agente moral segue uma máxima de ação que vai em direção diametralmente oposta do dever ser marcado pelo Imperativo Categórico.

No caso de Engels, ele descreve que o burguês não consegue sentir a dor do proletário e isso evidencia a corrupção dos seus sentimentos morais. Nela, o que está em jogo na hora de

constituem a personificação de categorias econômicas, as portadoras de determinadas relações e interesses de classes. Meu ponto de vista, que apreende o desenvolvimento da formação econômica da sociedade como um processo histórico-natural, pode menos do que qualquer outro responsabilizar o indivíduo por relações das quais ele continua a ser socialmente uma criatura, por mais que, subjetivamente, ele possa se colocar acima delas" (MARX, 2013b, p. 80, grifo meu). 
refletir sobre a corrupção moral do burguês é sua incapacidade de se sensibilizar com a dor do outro e o fato de que seu agir não está regrado por uma lei prática universal. Sendo assim, cabe afirmar que os postulados do jovem Engels fogem do quadro da ética kantiana e o aproximam do paradigma da teoria ética smithiana.

\subsubsection{A corrupção moral da classe proletária e a responsabilidade burguesa}

Anteriormente vimos que, no seu primeiro artigo, Engels analisava a imoralidade do comércio, do latifundiário e do acionista da Bolsa. Vimos também como, no seu primeiro livro, seu foco de estudo muda, passando a analisar a condição da classe trabalhadora inglesa e suas tensões com a classe burguesa. Nesse marco de análise, ele realiza as críticas contra a moralidade burguesa nos termos até aqui apontados. Porém, outro elemento de teor moral totalmente novo que aparece na Introdução do livro em questão são suas reflexões sobre a corrupção moral dos próprios proletários no marco do industrialismo inglês. Engels propõe uma genealogia da corrupção moral da classe trabalhadora, a qual explica como aquela massa de camponeses embrutecidos pela vida no campo é, com o desenvolvimento industrial, expropriada e expulsada da terra, sendo materialmente forçada a trabalhar nas fábricas das grandes cidades inglesas. O estilo da escrita da referida introdução evidencia claramente o rompimento com a produção filosófica idealista tipicamente alemã e a influência do estilo filosófico-historiográfico inglês, que será a base para o desenvolvimento do materialismo histórico marxiano ${ }^{17}$. A principal fonte a partir da qual Engels se envolve com este estilo filosófico é A Riqueza das Nações de Adam Smith, obra cujo livro III está dedicado especificamente a descrever de forma detalhada a transição do regime feudal para o capitalismo europeu emergente. Nesse livro, o autor vai explicar os motivos materiais a partir dos quais uma massa camponesa que fugia do campo foi criando os burgos e posteriormente,

\footnotetext{
${ }^{17}$ Uma análise detalhada das particularidades das diferenças entre o estilo filosófico alemão e inglês estão para além dos objetivos do presente trabalho. Aqui cabe apenas dizer que ao falar em estilo filosófico historiográfico inglês, quero apontar para as peculiaridades de um estilo filosófico de escrita cujo nascimento pode ser datado a partir da obra de Hobbes (2005), e que sofrerá uma significativa evolução com Hume (1988, 2004, 2011). Tratase de um estilo filosófico-literário que opta por se basear em fatos históricos para, dessa forma, alcançar postulados filosóficos de caráter geral. A principal fonte a partir da qual Engels se envolve com este estilo filosófico, é A Riqueza das Nações de Adam Smith. Dito isso, cabe simplesmente afirmar que o materialismo histórico de Marx e Engels deve muito à filosofia inglesa.
} 
uma nova classe social, a burguesia. Com base nesse suporte teórico/referencial, Engels começa sua reconstrução histórica em termos puramente smithianos ${ }^{18}$. Ele afirma:

É fácil adivinhar o caráter moral e intelectual dessa classe [os camponeses pré-industriais]. Afastados das cidades, nelas praticamente não entravam porque entregavam, mediante o pagamento do seu trabalho, o fio e o tecido a agentes itinerantes - de modo que, velhos moradores das proximidades das cidades, nunca haviam ido a elas, até o momento em que as máquinas os despojaram de seu ganha-pão, obrigando-os a procurar trabalho na cidade. Seu nível intelectual e moral era o da gente de campo, à qual, de resto, estavam geral e diretamente ligados através de seus pequenos arrendamentos. [...] Eram gente "respeitável" e bons pais de família, viviam segundo a moral porque não tinham ocasião de ser imorais, já que nas imediações não havia bordéis e o dono da taberna onde eventualmente saciavam a sede era também um homem respeitável e, na maior parte das vezes, um grande arrendatário que fazia questão de ter boa cerveja, de manter as coisas em ordem e de deitar cedo. (ENGELS, 2013, p. 46-7)

É assim como Engels descreve um cenário no qual os camponeses não eram empurrados a cometer excessos morais. Aqui, ele ilustra as condições materiais de vida do camponês do século XVI e salienta os motivos pelos quais uma massa de pessoas que, mesmo sem nenhum tipo de educação formal e castigada com a árdua vida no campo, não incorria em atos moralmente questionáveis. Mas, dito isso, nosso autor mostrará como, logo que o processo combinado de expropriação dos pequenos camponeses das terras para favorecer a produção de lã e a assimilação dessas populações desamparadas nas fábricas das cidades, os vícios morais da emergente classe proletária teriam terreno fértil para proliferar. De todos os vícios morais que essa novíssima classe social pode desenvolver, Engels põe ênfase em três deles, a saber, (1) o alcoolismo nos homens, (2) a imoralidade sexual das mulheres ${ }^{19}$ e (3) a delinquência.

(1) O alcoolismo tão próprio dos proletários da Inglaterra do século XIX é atribuído por Engels à vida dura que levavam na Inglaterra industrial da época nos seguintes termos:

Todas as tentações e ilusões se juntam para induzir os trabalhadores ao alcoolismo. A aguardente é para eles a única fonte de prazer e tudo concorre para que a tenham à mão. $\mathrm{O}$ trabalhador retorna à casa fatigado e exausto;

\footnotetext{
${ }^{18}$ A respeito desta apreciação, cabe referir a já citada frase de Adam Smith (1983, p. 322, grifo meu), onde nosso autor versa sobre "a beleza do campo, os prazeres de uma vida campestre, a tranquilidade de espírito que ela proporciona, [...] onde a injustiça das leis humanas não [perturbam a ordem natural das coisas]".

19 No presente trabalho não pretendo fazer uma análise do status moral do alcoolismo e de certos comportamentos sexuais das mulheres, tais como ter relações sexuais com homens casados etc. Para os propósitos desta pesquisa é suficiente apontar para o fato de que, no século XIX, em tempos da publicação do livro de Engels, os proletários eram acusados de serem pessoas de costumes indecentes, em grande parte, por seus hábitos alcoólatras e pelos seus costumes sexuais promíscuos.
} 
encontra uma habitação sem nenhuma comodidade, úmida, desagradável e suja; tem urgente necessidade de distrair-se; precisa de qualquer coisa que faça seu trabalho valer a pena, que torne suportável a perspectiva do amargo dia seguinte. (ENGELS, 2013, p. 142)

Além de Engels (2013, p. 142, grifo meu) mencionar as condições físicas que levam o proletário à bebida, ele também acrescenta alguns outros pesares típicos do proletário inglês do século XIX, tais como a educação deficiente, a exposição a maus exemplos, tais como amigos e pais alcoólatras, para concluir que "esses e cem outros fatores que operam tão fortemente não nos permitem, na verdade, censurar aos operários sua inclinação para o alcoolismo".

Finalmente, Engels apontará para o fato de que o alcoolismo representava um problema não de alguns indivíduos, mas de uma classe toda. Ele afirma:

[O] alcoolismo deixa de ser um vício de responsabilidade individual; tornase um fenômeno, uma consequência necessária e inelutável de determinadas circunstâncias que agem sobre o sujeito que - pelo menos no que diz respeito a elas - não possui vontade própria, que se tornou - diante delas um objeto; aqui a responsabilidade cabe aos que fizeram do trabalhador um simples objeto. (ENGELS, 2013, p. 142-3)

A presente citação de Engels releva duas coisas em relação a sua concepção do alcoolismo entre os operários. (a) Em primeiro lugar, cabe apontar para a ideia engelsiana já adiantada, segundo a qual o fenômeno do alcoolismo ser um mal próprio da classe operária e não de este ou aquele trabalhador. $\mathrm{Na}$ argumentação engelsiana, o álcool entra na vida do trabalhador sem que ele tenha como resistir. Isso faz que os indivíduos que possuem o costume de se embriagar após suas longas jornadas de trabalho, às vezes de mais de 16 horas, não são verdadeiramente imputáveis de responsabilidade moral. (b) Como segundo aspecto a destacar, nosso jovem autor sustenta que a responsabilidade pelo alcoolismo dos trabalhadores fabris é puramente daqueles que, através de uma relação laboral degradante, os forçam a uma vida atrelada ao vício do álcool. O importante desta tese engelsiana radica no fato de que, a partir dela, rejeita-se a possibilidade de que os "bons burgueses", aqueles pais de família exemplares, e a alta sociedade inglesa continuassem acusando a classe trabalhadora com base em argumentos moralistas que colocavam a responsabilidade moral da imoralidade proletária nos próprios trabalhadores; acusações tipicamente cunhadas pelas altas classes sociais inglesas, as quais, na década de 1840, visavam, entre outras coisas, minar as bases do cartismo. A partir da reflexão de Engels, longe de a burguesia estar em 
condições de criticar moralmente os hábitos pouco refinados, grosseiros e degradantes da classe trabalhadora inglesa, ela passa agora a ser considerada como a responsável material de que os trabalhadores desenvolvam esse tipo de hábito moralmente questionável. Nesses termos, a burguesia se torna responsável do embrutecimento e da imoralidade da classe trabalhadora.

(2) Engels também analisa os motivos pelos quais a prostituição e a degradação moral feminina é tão comum entre as mulheres proletárias. Mais uma vez, o jovem autor oferece uma resposta que põe ênfase nas relações de produção imperantes no industrialismo inglês ${ }^{20}$. A partir de estudos sobre a realidade fabril inglesa, Engels afirma:

[C]omprende-se que a servidão na fábrica, como qualquer outra e mais que qualquer outra, confira ao patrão o jus primae noctis [direito à primeira noite]. O industrial é o senhor do corpo e dos encantos de suas operárias. A ameaça de demissão é uma razão suficiente em $90 \%$, senão em $99 \%$, dos casos para anular qualquer resistência das jovens que, ademais, não têm muitos motivos para preservar sua castidade. (ENGELS, 2013, p. 186-7)

Segundo a argumentação engelsiana, as relações de poder assimétricas próprias do

trabalho assalariado tornam a mulher trabalhadora vulnerável perante os interesses libidinosos do seu empregador, ao ponto de que "[s]e ao rico senhor lhe agrada a mulher ou a filha do operário, basta-lhe um aceno para constrange-la a sacrificar seus encantos" (ENGELS, 2013, p. 216, grifo meu). A partir da descrição da situação da mulher trabalhadora na sociedade capitalista da Inglaterra de metade de século XIX, Engels mostra mais uma vez que a corrupção moral do agente acontece devido às relações de produção capitalista e não, por exemplo, a qualquer vício moral de uma natureza humana particular do trabalhador. Se as mulheres da classe trabalhadora se entregam sexualmente aos senhores capitalistas, isso se deve a que as condições materiais as arrastam a fazê-lo. Nesse caso, não haveria vício natural, mas apenas corrupção moral. Trata-se de mais um caso no qual a alta sociedade burguesa e seus sócios latifundiários não podem criticar moralmente à classe trabalhadora, dado que os que pautam as relações de produção naquela sociedade são eles mesmos e não aqueles ditos "imorais".

(3) O jovem Engels ainda versa sobre mais um elemento fortemente associado à ética proletária, a saber, a delinquência. Nesse caso, podem-se observar algumas diferenças com os fenômenos do alcoolismo e da imoralidade sexual feminina.

\footnotetext{
${ }^{20}$ Esse pensamento engelsiano chegou a alcançar um lugar no Manifesto Comunista, quando seus autores versaram sobre a crítica da "comunidade das mulheres" (MARX-ENGELS, 2010, p. 55-6).
} 
A educação moral, que não é oferecida aos operários nas escolas, não lhes é propiciada em nenhum outro momento de sua vida - nem mesmo aquela educação moral que, aos olhos, da burguesia, tem algum valor. A posição social e o meio ambiente do operário incitam-no fortemente à imoralidade. Ele é pobre, sua vida não tem atrativos, quase todos os prazeres lhe são negados, os rigores da lei para ele não são nada de terrível; então, por que ele deveria refrear seus desejos, por que deveria deixar ao rico o gozo de seus bens sem apropriar-se de uma parte deles? Quais são as razões que o operário tem para não roubar? É muito linda a frase: "A propriedade é sagrada"; ela soa como música aos ouvidos burgueses, mas, para quem nada possui, esse caráter sagrado desaparece automaticamente. [...] A miséria só permite ao operário escolher entre deixar-se morrer lentamente de fome, suicidar-se ou obter aquilo de que necessita onde encontrar - em outras palavras, roubar. (ENGELS, 2013, p. 154-5, grifos meus)

Da mesma forma que nos casos acima analisados, o caso do roubo deriva das condições materiais que a classe trabalhadora sofre no marco da forma de produção capitalista. Porém, diferente do alcoolismo e da imoralidade sexual das mulheres, os altos índices de delinquência da classe trabalhadora não são apresentados por Engels como uma vitória para a burguesia. O proletário alcoólatra ajudará na sua condição de consumidor, a enriquecer o setor da burguesia que opera no ramo das cervejas e destilados. O harém de proletárias saciará a apetite sexual do seu senhor capitalista. Porém, Engels mostra como o fenômeno da delinquência proletária impacta o mundo burguês de forma severa e faz a classe dominante pagar algumas das consequências de sustentar as relações de produção capitalista. Engels transfere mais uma vez responsabilidade moral da classe trabalhadora para a classe burguesa. Esta última é a que marca as regras do jogo e, portanto, ela é a responsável material da corrupção moral dos operários ingleses ${ }^{21}$.

Segundo Engels, os três casos de degradação moral da classe trabalhadora inglesa seguem o mesmo padrão. Neles, ela acontece pelas condições materiais da classe proletária, isto é, pela sua situação desfavorável no marco das relações de produção capitalistas na qual eles vivem. As dificuldades econômicas e a vulnerabilidade extrema dos operários ingleses provocariam um "esgotamento das suas forças físicas e morais" (ENGELS, 2013, p. 137, grifo meu) que os levariam a desenvolver estilos de vida moralmente questionáveis. Essa

\footnotetext{
${ }^{21}$ Smith já dizia na Riqueza das nações: "[E]mbora o interesse da classe trabalhadora esteja intimamente ligado ao interesse da sociedade, o trabalhador é incapaz tanto de compreender esse interesse quanto de compreender a vinculação do interesse da sociedade ao seu próprio. Sua condição não lhe deixa tempo para receber a necessária informação, e sua educação e hábitos costumam ser tais que o tornam inapto para discernir, mesmo que esteja plenamente informado. Por isso, nas deliberações públicas, sua voz é pouco ouvida e ainda menos levada em conta, excetuadas algumas ocasiões específicas, quando suas reivindicações são animadas, incitadas e apoiadas pelos seus empregadores, que no caso lutam não pelos objetivos dos trabalhadores, mas pelos seus próprios" (SMITH, 1983, p. 228, grifo meu).
} 
ideia de degradação moral desenvolvida pelo nosso autor possui, como já foi afirmado, claros pontos de contato com a teoria ética smithiana. Em ambos os casos os agentes morais veem seus sentimentos morais serem corrompidos; os agentes morais incorrem em atos que vão contra a moralidade, devido a que sua percepção do que está certo e do que está errado foi distorcida. Não obstante, cabe ainda dizer que elas também possuem diferenças substantivas. No caso de Smith, é a Natureza que age sobre a natureza humana para produzir o efeito por ela desejado, qual seja, estabelecer uma determinada ordem social. É por motivos naturais que o sujeito persegue a riqueza cegamente, bajula os ricos e poderosos ao ponto de considera-los superiores naturais e se insensibiliza perante o sofrimento dos pobres. No caso de Engels, são as relações de produção impostas por uma classe as que corrompem tanto aos burgueses quanto aos proletários. Dessa forma, o jovem Engels supera a concepção de natureza humana smithiana. No caso dos capitalistas, seu inesgotável afã por lucro os corrompe e os torna insensível perante o sofrimento proletário. No caso dos trabalhadores, a corrupção de seus sentimentos morais acontece a partir do "desgaste" moral associado a viver numa situação material de extrema vulnerabilidade. Sendo assim, para Engels, o desgaste moral dos proletários não acontece por causa das particularidades da natureza humana. O enfraquecimento de suas convicções morais e a consequente conduta imoral dos trabalhadores ingleses têm lugar a partir de uma vida cheia de privações materiais e constante luta pela sobrevivência. Reféns das relações de produção capitalistas no quadro económico por elas criado, eles incorrem em atos tipificados como imorais.

A seguir, observaremos mais um elemento do pensamento do jovem Engels que o aproxima da ética smithiana

\subsubsection{A humanidade da classe proletária}

Até agora, vimos os três fenômenos sociais que, segundo o jovem Engels, representariam um desgaste moral da classe proletária. Vimos também que essa corrupção moral do proletário é vista pelo autor como uma consequência necessária das condições materiais nas quais a classe proletária é obrigada a viver nas grandes cidades industriais britânicas das décadas de 1830 e 1840 e que Engels transfere a responsabilidade moral dessa corrupção à classe burguesa. Porém, em A situação da classe trabalhadora na Inglaterra 
Engels também aponta para mais um aspecto relevante da moralidade proletária, qual seja, seu lado humanista e seu paralelismo com a desumanidade burguesa. Partindo de algumas constatações e relatórios clericais da época, ele afirma:

\begin{abstract}
Na vida cotidiana, o operário é muito mais humano que o burguês. Assinalei anteriormente como os mendigos quase só costumam apelar aos operários e que, de um modo geral, os trabalhadores contribuem muito mais que os burgueses na ajuda aos pobres. [...] Experimentando pessoalmente uma vida penosa, são capazes de sentir compaixão pelos que têm dificuldades. Para os operários, qualquer homem é um ser humano; para os burgueses, o operário é menos que um homem. Por isso os operários são mais sociáveis, mais amáveis; para eles, o dinheiro vale unicamente pelo que permite comprar, ao passo que, para o burguês, o dinheiro possui um valor particular, intrínseco, o valor de um deus, o que transtorna o burguês num vulgar e sórdido "homem do dinheiro". (ENGELS, 2013, p. 162-3)
\end{abstract}

Nesta passagem, Engels mais uma vez se serve de aspectos próprios da teoria ética smithiana. O que Engels analisa aqui é a capacidade intacta de o proletariado simpatizar com todos aqueles que estão sofrendo, isto é, aquela capacidade que os burgueses perderiam em relação aos proletários. Anteriormente vimos que, perante os olhos do nosso autor, a imoralidade da classe burguesa estava marcada pela sua falta de sensibilidade pelo mal-estar da classe trabalhadora. A corrupção de seus sentimentos morais tinha como resultado que essa classe, sempre ávida por dinheiro, não se importava que, para obter seu tão desejado lucro, tivesse que afundar a classe proletária na maior das misérias (ENGELS, 2013, p. 307-8). Na direção contrária, Engels expõe como, no marco das relações de produção capitalistas, o proletariado inglês dava claros sinais de ser mais humano que a classe burguesa. Ser mais humano significa, para nosso autor, manter a capacidade de simpatizar com os pobres, mendigos e indigentes, isto é, aqueles que são dignos de que os outros sintam a dor que eles sentem. Assim, a perda dessa capacidade humana natural que, no caso da classe burguesa, representaria sua degradação moral e consequente desumanização, não teria lugar entre a classe trabalhadora.

Com o referido quadro, Engels nos oferece as duas caras da moralidade burguesa e proletária. No primeiro caso, eles são pessoas que gozam de boa reputação moral: são responsáveis, bons pais de família, educados, possuem hábitos refinados etc. Porém, para nosso autor, eles não somente são os responsáveis materiais pela brutalidade e o mal-estar da classe proletária. A desumanização burguesa condena a classe trabalhadora à indigência e a empurra na direção da corrupção dos seus sentimentos morais. Os 
proletariados, pelo contrário, possuem costumes nada refinados e são sistematicamente taxados de imorais, dados seus típicos problemas de adição à bebida, hábitos sexuais deploráveis, seus crimes contra a propriedade etc. Porém, eles mantêm intacto o sentimento moral de simpatia pelos indigentes e isso, desde a ótica de Engels, os torna mais humanos que aqueles refinados burgueses. Eles ainda possuiriam o pouco de humanidade que pode existir no marco das relações de produção capitalista.

3.2.3 O espaço das críticas morais de Engels em A situação da classe trabalhadora da Inglaterra

$\mathrm{Na}$ segunda parte do presente trabalho vimos que os primeiros trabalhos de Engels possuem diversas reflexões morais sobre os principais agentes das relações de produção capitalista - burgueses, operários, banqueiros, comerciantes etc. Vimos também que entre 1844 e 1845, Engels refina suas considerações morais, passando a evitar críticas morais pouco elaboradas e a analisar fatos econômicos da sociedade inglesa do seu tempo de um modo verdadeiramente científico e aprimorado. Cabe, agora, ver qual é o papel das considerações morais que aparecem em A situação da classe trabalhadora na Inglaterra.

É certo que, no seu primeiro livro, Engels acusa a burguesia de ser uma classe imoral e inclusive chega a responsabilizá-la pela condição paupérrima da classe trabalhadora inglesa. Contudo, pese a que Engels critique a moralidade da classe burguesa, ele não justifica a ação revolucionária por parte dos operários baseado na imoralidade da classe burguesa. Prova disso é a seguinte passagem:

\footnotetext{
Mesmo que deixe de lado as diversas provas aqui oferecidas, apoiadas em inúmeros exemplos específicos, o leitor haverá de conceder facilmente que os operários ingleses não podem estar felizes nas condições em que vivem; haverá de conceder que sua situação não é aquela em que um homem - ou uma classe inteira de homens - possa pensar, sentir e viver humanamente. Os operários devem, portanto, procurar sair dessa situação que os embrutece. (ENGELS, 2013, p. 247)
}

Nesse trecho, pode-se perceber que Engels abre mão de se servir qualquer tipo de crítica moral contra a burguesia para justificar a augurada revolta da classe trabalhadora. Ele não postula o advento de tão aguardada revolução do proletariado a partir de qualquer tipo de justificação de cunho moralista. Longe disso, o augúrio da revolução social feito pelo nosso autor está fundado na própria situação da classe 
operária e não nos eventuais vícios morais da classe burguesa. Dada sua condição material, caberia segundo nosso autor, esperar que o proletariado leve adiante uma verdadeira guerra contra a classe burguesa sem a necessidade de levar em consideração qualquer tipo de princípio moral. As condições de vida paupérrimas nas quais estava obrigada a viver a avassaladora maioria dos trabalhadores da Inglaterra era motivo suficiente para o desencadeamento de uma feroz intensificação da luta de classes entre operários e donos dos meios de produção. Dessa fora, a argumentação de Engels possui uma vantagem estratégica muito grande em relação a uma eventual apologia da ação revolucionária cunhada no terreno da moralidade: ela não precisa demonstrar que a burguesia, enquanto classe que vai contra os interesses dos proletários, age de forma imoral, o que de certa forma acaba sendo difícil de demonstrar no plano teórico. Uma das grandes virtudes da teoria marxiana foi apontar para o fato de que, historicamente, a reflexão moral foi um terreno muito fértil para a defesa e difusão dos interesses das classes dominantes e de que, no que se refere às relações de produção capitalista, o simples fato de se adentrar no debate moral mina os interesses da classe proletária e favorece a classe burguesa. Assim, a partir do espírito da crítica marxiana das relações de produção capitalistas que seus autores lhe imprimiram, no marco da teoria marxista, qualquer reflexão de tipo moral deve adotar um caráter materialista histórico, isto é, ele não deve cair na tentação de se adentrar em debates pura e exclusivamente teóricos sobre o bem, a justiça e o agir moral. No seu livro, o jovem Engels, futuro coautor da teoria marxiana, outorga à reflexão moral o caráter que lhe favorece à teoria marxista, qual seja, um caráter despojado das formas puras da reflexão ético/moral. Sendo assim, a partir da observação das condições materiais dos proletários Engels pode postular a necessidade de uma revolução social sem se adentrar demasiado no campo difuso dos traços morais da sociedade capitalista. Dessa forma, a explicitação de que a burguesia é imoral não atua, nem de perto, como base única para a justificação da revolução social, mas como um dos seus tantos elementos complementares do seu discurso legitimatório.

\section{MARX E SUA INFLUÊNCIA SOBRE ENGELS}

$\mathrm{Na}$ segunda parte deste texto, realizei uma análise das primeiras duas publicações de Engels, a saber, seu primeiro artigo de 1844, publicado nos Anais Franco-Alemães e seu livro de 1845, tentando apontar para as principais características do 
pensamento moral do jovem filósofo e o espaço que tal pensamento ocupa na sua obra de juventude. No primeiro desses trabalhos, observamos como Engels criticava as relações econômicas do seu tempo desde um viés extremada e puramente moralista, isto é, o tipo de crítica que Marx se recusaria a realizar ao longo da sua obra. Vimos também como, no seu primeiro livro, Engels refinaria suas críticas morais, direcionando ela contra a classe burguesa. Nessa direção, um dos aspectos salientados foi a proximidade das considerações morais do jovem Engels com a teoria ética smithiana ${ }^{22}$, tema que, até hoje, não é levado em consideração no marco da doutrina marxista.

A partir da comparação entre os postulados de seu primeiro artigo e o livro que publicará tão somente um ano depois, foi possível observar a progressiva transformação engelsiana de crítico moralista das relações de produção capitalista em verdadeiro marxista, isto é, num pensador que tentará entender a necessária revolução do proletariado não apenas a partir de considerações puramente morais, mas de elementos de ordem econômico/políticos. Nos seus primeiros passos como intelectual crítico das relações de produção capitalista, o jovem Engels possui uma clara influência do cartismo e especial influência de Robert Owen, o pai inglês da crítica moral do sistema capitalista da época. No entanto, no período de 1845 em diante, inclusive a partir de trabalhos em coautoria, tais como A ideologia alemã(2014) ou A sagrada família (2015), é possível acompanhar a mudança de perfil do trabalho intelectual engelsiano. Nessa nova fase, não haverá espaço para reflexões puramente morais, senão uma crítica da economia política e a construção de uma verdadeira teoria da revolução de bases materiais. Após ter se autodeclarado marxista, ele nunca mais teria caído na tentação de esboçar sequer uma crítica moral do capitalismo. Ele, por clara influência de Marx, mudou da crítica owenista para a produção teórica visando a prática política e a ação estratégica.

Aqui tão somente resta dizer que todos os textos que Engels publicou, tanto antes da morte de Marx, quanto após o falecimento de seu grande amigo, seja para discutir sobre questões de moradia (ENGELS, 2015), seja para propor sua tese sobre a origem da família (1984) etc. - isso enquanto levava adiante um trabalho colossal como editor dos tomos II e III

\footnotetext{
${ }^{22}$ Uma vez observados os pontos em comum da teoria ética com as considerações morais do jovem Engels, cabe apontar que alguns dos traços da ética smithiana também transparece, mesmo que de forma tímida, nos escritos engelsianos de maturidade. Um claro exemplo desse fato tem lugar num trecho do seu trabalho Do socialismo utópico ao socialismo científico de 1860, onde Engels reproduz a tese smithiana de que os pobres consideram os ricos e poderosos como seus superiores naturais. Ele afirma: "[O] parlamentarismo é uma excelente escola para ensinar o respeito à tradição; se a burguesia olha com veneração e temor religioso o que lord Manners chamava ironicamente 'nossa velha nobreza', a massa dos operários olha com respeito e deferência os burgueses que estava habituada a considerar como seus 'superiores'. O operário inglês era, há uma quinzena de anos, o operário modelo, cuja respeitosa deferência por seu patrão e timidez em reclamar seus direitos consolavam nossos economistas da escola dos Katheder-Socialisten das incuráveis tendências comunistas e revolucionárias do proletariado de sua própria nação" (ENGELS, 2011, p. 46, grifo meu).
} 
do Capital (MARX, 2014; 2017) - foram sempre alinhados com o espírito marxiano, isto é, deixando de lado a teoria ética para se dedicar em cheio à teoria econômico/política. Uma vez que jovem Engels tornou-se marxista, ele jamais voltou atrás e as reflexões sobre a moralidade adotaram seu perfil politizado tão caro ao marxismo. 


\section{REFERÊNCIAS}

ARISTÓTELES. A política. Madrid: Gredos, 1988.

ENGELS, Friedrich. Esboço de uma crítica da Economia Política. Temas de Ciências Humanas. São Paulo, n. 5, p. 1-29, 1979.

ENGELS, Friedrich. A origem da família, da propriedade privada e do Estado. Rio de Janeiro: Civilização brasileira, 1984.

ENGELS, Friedrich. Do socialismo utópico ao socialismo científico. São Paulo: Edipro, 2011b.

ENGELS, Friedrich. A situação da classe trabalhadora da Inglaterra. São Paulo: Boitempo, 2013.

ENGELS, Friedrich. Sobre a questão da moradia. São Paulo: Boitempo, 2015.

ENGELS, Friedrich. Lei do valor e taxa de lucro. In: MARX, Karl. O capital. Tomo III. São Paulo: Boitempo, 2017.

FEUERBACH, Ludwig. A essência do cristianismo. Petrópolis: Vozes, 2013.

FREDERICO, Celso. O jovem Marx. 1843-1844: as origens da ontologia do ser social. São Paulo: Expressão popular, 2009.

HEGEL, Friedrich. Rasgos fundamentales de la Filosofía del Derecho o compendio de Derecho natural y Ciencia de Estado. Madri: Biblioteca nueva, 2000.

HERZOG, Lisa. Inventing the market. Hegel, Smith, and Political Theory. Oxford: Oxford University Press. 2013.

HOBBES, Thomas. Leviatán. Buenos Aires: Fondo de cultura económico, 2005.

HUME, David. Escritos sobre economia. São Paulo: Nova cultural, 1988. (Os economistas)

HUME, David. Da origem do governo. In: HUME, David. Ensaios morais, políticos $e$ literários. São Paulo: Nova cultura, 2004. Não paginado. (Os pensadores).

HUME, David. Tratado da natureza humana. São Paulo: Unesp, 2000.

HUME, David. Investigação sobre o entendimento humano. São Paulo: Hedra, 2011.

KANT, Inmanuel. Fundamentación de la metafísica de las costumbres. San Juan: Pedro. M. Rosario Barboza, 2007.

KANT, Inmanuel. Ideia de uma história universal com um propósito cosmopolita. In: A paz perpétua e outros opúsculos. p. 21-37. Lisboa: Edições 70, 2008. 
LÖWY, Michael. A teoria da revolução no jovem Marx. São Paulo: Boitempo, 2012.

MANDEVILLE. Bernard de. La fábula de las abejas, o cómo los vicios privados hacen la prosperidad pública. Madrid: Fondo de Cultura Económica, 1982.

MARX, Karl. Salário, preço e lucro. São Paulo: Edipro, 2004.

MARX, Karl. Contribuição à crítica da economia política. São Paulo: Expressão popular, 2008.

MARX, Karl. A questão judaica. São Paulo: Boitempo, 2010.

MARX, Karl. Crítica da Filosofia do Direito de Hegel. São Paulo: Boitempo, 2011a.

MARX, Karl. Crítica da Filosofia do Direito de Hegel - Introdução. São Paulo: Boitempo, 2011b.

MARX, Karl. Grundrisse. São Paulo: Boitempo, 2011.

MARX, Karl. O capital. Tomo I. São Paulo: Boitempo, 2013a.

MARX, Karl. Posfácio da segunda edição. In: $O$ capital. Tomo I. São Paulo: Boitempo, 2013b.

MARX, Karl. Manuscritos econômico-filosóficos. São Paulo: Boitempo, 2014a.

MARX, Karl. O capital. Tomo II. São Paulo: Boitempo, 2014b.

MARX, Karl. O capital. Tomo III. São Paulo: Boitempo, 2017.

MARX, Karl; ENGELS, Friedrich. Manifesto comunista. São Paulo: Boitempo, 2010.

MARX, Karl; ENGELS, Friedrich. A sagrada família. São Paulo: Boitempo, 2013.

MARX, Karl; ENGELS, Friedrich. A ideologia alemã. São Paulo, Boitempo, 2014.

NETO, José. Apresentação. Em: A situação da classe trabalhadora na Inglaterra. São Paulo: Boitempo, 2013.

OWEN, Robert. Essays on the Principle of the Formation of the Human Character, and the Application of the Principle to Practice. Londres: Cadell and Davis Strand, 1813.

PLATÃO. A república. Lisboa: Calouste Gulbenkian, 2011.

RICARDO, David. Princípios de Economia Política e Tributação. São Paulo: Nova Cultural, 1982.

SMITH, Adam. A riqueza das nações. Volume I. São Paulo: Nova Cultural, 1983.

SMITH, Adam. La teoría de los sentimientos morales. Madrid: Alianza, 2004. 